\title{
Pengaruh Kualitas Produk Kerudung Rabbani terhadap Tingkat Kepuasan Konsumen Di Kota Bandung
}

\author{
${ }^{1}$ Ermina Tiorida, ${ }^{2}$ Tangguh Dwi Pramono, ${ }^{3}$ Sifauziah \\ Jurusan Administrasi Niaga, Politeknik Negeri Bandung, Bandung 40012 \\ E-mail: ermina.tiorida@polban.ac.id
}

\begin{abstract}
Bandung is the center of Muslim fashion in West Java even at the national level. This causes intense business competition in the world of Muslim fashion. To that end, an important role that must be performed by a company is to prioritize product quality and product innovation as a basis for attracting customer so that customer can feel satisfaction from the quality of the products produced. According to Google trends Rabbani trends also experienced a decline in customer interest in the purchasing Muslim fashion. And the results of distributing pre-research questionnaires obtained $70.45 \%$ or 31 people were disappointed with the quality of their muslim fashion, this resulted in customer not satisfied with the Rabbani. This study aims to determine how the quality and innovation of Rabbani products to customer satisfaction in the city of Bandung. According to Garvin (1987) there are eight dimensions to test product quality variables, namely performance, features, reliability, conformance, durability, serviceability, aesthetic and perceived quality. Customer satisfaction is measured by three dimensions, namely overall quality, customization and reliability. The study was conducted using quantitative methods. The sampling technique using non-probability sampling techniques and questionnaires were distributed to Rabbani customer in Bandung as many as 150 respondents. Analysis of research data using SEM PLS (Partial Square Structural Equation Modeling) with SmartPLS 3.0 software. the results showed that product quality and innovation had a significant effect on customer satisfaction.
\end{abstract}

Keywords: Product Quality, Product Innovation, customer satisfaction

\section{A. PENDAHULUAN}

Seiring berkembangnya zaman, trend busana muslim di Indonesia terus mengalami perkembangan yang sangat pesat. Menurut kementerian perindustrian, [1] industri fesyen memiliki peran penting dalam perekonomian nasional, pasalnya berdasarkan data Badan Pusat Statisik (BPS) [2] industri fesyen pada tahun 2016 berhasil menyumbang kontribusi terhadap PDB nasional sebesar 18,01\% atau setara dengan 166 triliun. Dan pada tahun 2018 industri fesyen menghasilkan devisa nilai ekspor sebesar USD 8,2 miliar atau tumbuh sebesar $8,7 \%$ dari tahun sebelumnya. Hal tersebut juga disebabkan karena penduduk muslim di Indonesia setiap tahun terus mengalami peningkatan, sehingga seiring berjalannya waktu industri fesyen muslim dapat terus mengalami peningkatan penjualan dan perluasan pasar. Indonesia merupakan negara dengan penduduk muslim terbesar didunia. Berdasarkan data yang dilansir oleh The Pew Forum on Religion \& Public Life,[3] penganut agama Islam di Indonesia sebesar 209,1 juta jiwa atau 87,2\% dari total penduduk Indonesia.

Dengan demikian, perusahaan yang bergerak dalam bidang fesyen muslim sangat penting untuk menentukan strategi pemasaran yang tepat agar dapat bersaing dimasa mendatang dan selaras dengan tujuan perusahaan yang telah dibangun. Pada dasarnya semakin banyak pesaing, akan membuat konsumen dapat memilih sesuai dengan pilihannya dan berdasarkan kebutuhan serta manfaat yang konsumen dapatkan dari produk tersebut. Devi dan Sugiharto (2015) [4] apabila persaingan suatu industri semakin kompetitif, maka pelanggan relatif lebih mudah pindah ke pesaing. Sama halnya dengan industri fesyen muslim, apabila produsen tidak dapat memenuhi kebutuhan dan harapan konsumen, maka hal tersebut akan membuat konsumen beralih ke pesaing lainnya.

Oleh karenanya, pebisnis yang memilih dibidang fesyen muslim perlu membuat strategi pemasaran yang matang agar dapat membuat konsumen merasakan kepuasan dari produk tersebut, sehingga dapat menarik hati para konsumennya serta dapat menjaga konsumen dari para pesaingnya. Salah satu pebisnis yang memilih concern dalam bisinis fesyen muslim adalah Bapak H. Amry Gunawan 
dan Ibu Hj. Nia Kurnia selaku owner CV Rabbani. CV Rabbani merupakan perusahaan pelopor busana muslim di Indonesia. Berdiri sejak tahun 1991 dan memiliki visi yaitu menjadi perusahaan kerudung dan busana muslim terbaik dan terbesar di tahun 2020.

Penelitian ini didukung dengan datadata yang didapatkan melalui website serta penyebaran kuesioner pra penelitian guna mengetahui seberapa besar tingkat kepuasan konsumen dan kualitas produk kerudung Rabbani menurut konsumen di Kota Bandung. (Gambar 1) menunjukkan bahwa kerudung Rabbani mengalami penurunan minat konsumen dalam membeli kerudung

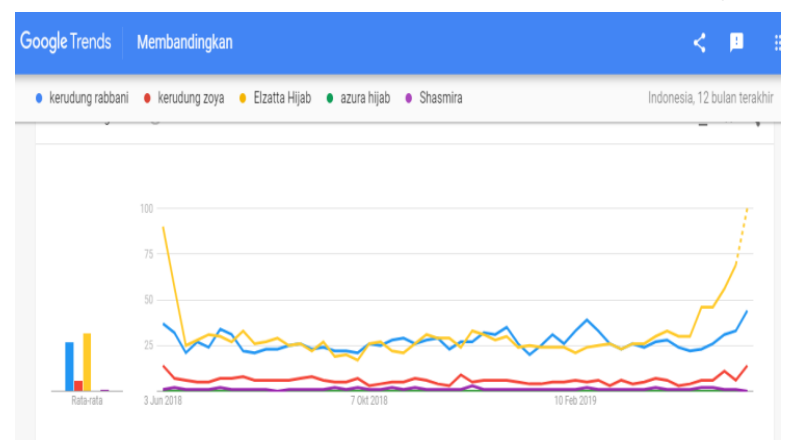

Gambar 1. Grafik Google trends

Selain itu diperoleh juga data yang diunggah oleh Frontier Consulting Group dan Majalah Marketing pada webnya yaitu Top Brand Award. Berikut data top brand award.

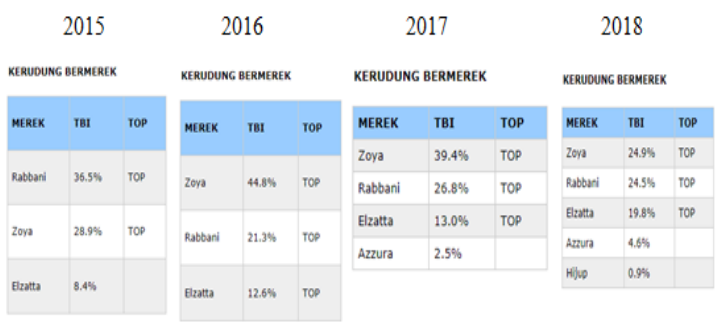

Gambar 2. Data Top Brand Index berbagai merek kerudung di Indonesia

Dapat dilihat pada gambar 1.3 bahwa trend kerudung Rabbani berdasarkan peringkat Top Brand Award menunjukkan penurunan yang cukup drastis, yaitu pada tahun 2015 dan 2016, top brand indeks menunjukan angka sebesar $36.5 \%$ menjadi $21.3 \%$ diikuti dengan penurunan peringkat yaitu dari peringkat pertama turun menjadi peringkat kedua. Akan tetapi pada tahun 2017, trend kerudung Rabbani mengalami

Eko dan Bisnis (Riau Economics and Business Reviewe) Volume 10, Nomor 4, 27 Desember 2019 kenaikan menjadi $26.8 \%$ naik sebesar $5.5 \%$ dan pada tahun 2018 mengalami penurunan kembali menjadi $24.5 \%$ dan dengan peringkat tiga tahun berturut-turut tetap di peringkat kedua. Irawan [5] merupakan seorang senior research executive frontier consulting group menjelaskan arti peringkat dalam riset marketing ini, yaitu bahwa arti peringkat dalam riset ini menunjukkan perkembangan merek menurut pandangan konsumen di Indonesia. Berdasarkan data tersebut, diduga bahwa produk kerudung Rabbani mengalami penurunan, dikarenakan strategi bauran pemasaran salah satunya yaitu kualitas produk yang ditetapkan oleh perusahaan tidak dapat meningkatkan kepuasan konsumen dalam memenuhi kebutuhan dan keinginannya. Hal ini pula kurang mendukung dengan visi yang dicanangkan oleh Rabbani yaitu menjadi perusahaan kerudung dan busana muslim terbaik dan terbesar di tahun 2020 mendatang.

Selain data yang didapatkan melalu pencarian di website dilakukan pula penyebaran melalui kuesioner berikut hasil pra penelitian yang disebarkan ke 44 responden melalui aplikasi goggle form guna menguatkan data yang sudah didapatkan, dari penyebaran kuesioner pra penelitian diperoleh bahwa $20.45 \%$ atau 9 responden merasakan kekecewaan terhadap harga yang ditawarkan oleh Rabbani. Pasalnya, harga yang ditawarkan tersebut semakin tinggi, namun kualitas produk masih tetap sama, bahkan kualitas produknya menurun. Dan $70.45 \%$ atau 31 responden mengatakan bahwa model kerudung Rabbani tidak kekinian atau tidak up to date dan terlihat kuno.

Dari penjelasan tersebut, dapat disimpulkan bahwa konsumen belum atau bahkan tidak merasakan kepuasan terhadap pemenuhan kebutuhan dan keinginannya. Menyatakan bahwa kepuasan (satisfaction) adalah perasaan senang atau kecewa seseorang yang timbul karena membandingkan kinerja yang dipersepsikan produk (atau hasil) terhadap ekspektasi mereka [6]. Apabila kinerja perusahaan

P.ISSN: 1410-7988 E.ISSN: 2614-123X 
tidak memenuhi harapan (ekspektasi) konsumen, maka konsumen akan tidak puas. Sedang apabila kinerja perusahaan sesuai dengan ekspektasi, maka konsumen akan merasa puas. Dan jika melebihi ekspektasi, maka konsumen akan sangat puas. Sehingga untuk mempertahankan konsumen yang sudah ada, perlu kiranya perusahaan memiliki orientasi terhadap konsumen. agar konsumen yang sudah ada tidak pergi ke pesaing lain. Maka dibutuhkan strategi untuk dapat memuaskan konsumen dengan cara meningkatkan kualitas dan inovasi produk.

\section{Kualitas Produk}

Kualitas merupakan totalitas fitur dan karakteristik produk atau jasa yang bergantung pada kemampuannya untuk memuaskan kebutuhan yang dinyatakan atau tersirat [7]. Sedangkan produk merupakan segala sesuatu yang dapat ditawarkan ke pasar untuk mendapatkan perhatian, dibeli, digunakan, atau dikonsumsi dan yang dapat memuaskan keinginan atau kebutuhan [8]. Dan kualitas produk adalah product quality is assessment of current expenditure experiences by the market serve. This built evaluate customization and consistenc of a given product and service. Yang artinya, kualitas produk adalah penilaian dari pengalaman berbelanja saat ini. Hal ini akan membentuk sebuah evaluasi kustomisasi dan konsistensi yang diberikan oleh suatu produk dan layanan. Kustomisasi yang dimaksudkan adalah skala untuk produk dan layanan dalam memenuhi kebutuhan konsumen dan konsistensi adalah skala untuk perusahaan dalam menawarkan produk atau layanan yang konsisten, identik dan bebas dari kekurangan yang tidak diharapkan.

Pada variabel kualitas produk terdapat dimensi-dimensi yang digunakan untuk dijadikan sebagai alat ukur penelitian ini, dimensi tersebut mengembangkan sistem pemikiran tentang kualitas produk dapat digambarkan dengan elemen-elemen dasar kkualitas produk yang terdapat dalam delapan dimensi, yakni: [9]

1. Kinerja (Performance), mengacu pada karakteristik operasi utama

Eko dan Bisnis (Riau Economics and Business Reviewe) Volume 10, Nomor 4, 27 Desember 2019 suatu produk yang dipertimbangkan atau diharapkan konsumen ketika hendak membeli produk tersebut.

2. Keistimewaan tambahan (Features), yaitu karakteristik pelengkap atau tambahan yang dapat meningkatkan daya tarik produk kepada konsumen. Features ini merupakan salah satu dari aspek sekunder kinerja.

3. Keandalan (Realibilty), yaitu kemungkinan bahwa suatu produk tidak akan gagal dalam periode waktu tertentu ketika digunakan.

4. Kesesuaian dengan Spesifikasi (Conformance,) ketepatan karakteristik produk dan layanan yang memenuhi standar yang telah ditetapkan sebelumnya.

5. Daya Tahan (Durability), yaitu mengukur panjang masa operasi suatu produk dapat terus digunakan.

6. Serviceability, yaitu meliputi kecepatan, kompetensi, kenyamanan, kemudahan dalam pemeliharaan dan penanganan keluhan yang memuaskan.

7. Estetika (Aesthethic), yaitu menyangkut produk yang terlihat dan terasa. Estetika merupakan penilaian pribadi dan refleksi dari preferensi individu terhadap suatu produk.

8. Kualitas yang dipersepsikan (Perceived quality), yaitu menyangkut citra dan reputasi produk serta tanggung jawab perusahaan terhadapnya.

\section{Inovasi Produk}

Inovasi adalah suatu langkah yang penting untuk menuju pasar yang baru dan mengatasi persoalan-persoalan. Onojaefe dan Nhepera (2017) menjelaskan inovasi adalah membuat kombinasi baru atas produk atau jasa, teknik proses produksi, dan struktur organisasi baru (Schumpeter, 1934). Masih dari sumber yang sama, Hall dan William (2008) menjelaskan inovasi sebagai suatu proses yang sistematik dalam

P.ISSN: 1410-7988 E.ISSN: 2614-123X 
mengenerasi, menerima dan mengimplementasi hal-hal yang baru yaitu yang mencakup ide-ide, proses, atau produk untuk meningkatkan pengalaman pelanggan, dan dirasakan sebagai produk baru oleh pelanggan.

Berdasarkan

penelitian

Schniederjans \& Shcniederjans (2015) ada beberapa tipe inovasi dapat disesuaikan dengan kondisi organisasi yaitu incremental product, incremental process, radical product, radical proces dan administrative. Dalam penelitian ini inovasi yang digunakan adalah inovasi produk baik secara incremental dan radikal. Inovasi incremental adalah perubahan minor terhadap disain, fungsi, harga, kuantitas dan fitur lain yang sesuai dengan kebutuhan pelanggan sekarang. Inovasi radikal mengacu kepada adopsi terhadap teknology baru untuk menciptakan permintaan yang tidak disadari oleh pasar. Konsep inovasi yang digunakan dalam peneltian ini adalah incremenal product (perluasan produk lini dan produk tiruan) dan radical praoduct (penciptaan produk baru).

\section{Kepuasan Konsumen}

Secara umum, customer satisfaction is [6] a person's feeling of pleasure or disappointment resulting from comparing a product's received performance (or outcome) in relations to the persons's expectation. Yang artinya kepuasan (satisfaction) adalah perasaan senang atau kecewa seseorang yang timbul karena membandingkan kinerja yang dipersepsikan produk (atau hasil) terhadap ekspektasi mereka.

Kepuasan atau ketidakpuasan adalah hubungan antara kemampuan suatu produk baik barang atau jasa, untuk menunjukkan kualitasnya secara nyata (aktual) dan kualitas produk yang seharusnya diberikan (should be) [10]. Hal ini dilihat dari persepsi pelanggan, di mana pelanggan akan memiliki perasaan positif atau negatif setelah mengkonsumsi suatu produk atau menerima suatu layanan. Perasaan tersebut dapat berupa reaksi yang muncul dari serangkaian

Eko dan Bisnis (Riau Economics and Business Reviewe) Volume 10, Nomor 4, 27 Desember 2019 pengalaman dalam proses konsumsi tersebut.

Juga mengatakan kepuasan menjadi suatu hal yang penting, sebab kepuasan dan kebahagiaan terhadap suatu layanan produk atau jasa bukan saja harapan dari para pemilik perusahaan dan para karyawan, tetapi juga merupakan harapan dari para pembeli atau pengguna produk atau jasa tersebut [11]. Darmadi menambahkan bahwa ada yang perlu diperhatikan, yaitu perusahaan sebagai produsen harus memberikan apa yang sebenarnya diinginkan dan menjadi kebutuhan para konsumen. Sebab apabila pembeli sudah merasa puas terhadap produk atau jasa yang mereka dapatkan, maka mereka dapat membantu dalam mempromosikan dan menyebarluaskan keberadaan perusahaan.

Selain itu, kepuasan pelanggan (customer satisfaction) tergantung pada kinerja terhadap ekspektasi konsumen [12]. Apabila kinerja perusahaan tidak memenuhi ekspektasi konsumen, maka konsumen akan merasa tidak puas. Sedang apabila kinerja perusahaan sesuai dengan ekspektasi, maka konsumen akan merasa puas. Dan jika melebihi ekspektasi, maka konsumen akan sangat puas. Pengertian kepuasan pelanggan menurut Kotler dan Armstrong sejalan dengan pelanggan melakukan evaluasi kuaitas yaitu bahwa customers evaluate quality by comparing their expectations with their perceptions of the product performance. If the product quality meets customer expectation, the customer is said to be satisfied when the product quality exceeds customer expectation, the customer is said to be delighted. In addition, if the product fails to meet customers' expectation, the customer is dissatisfied and there may be no repeat puchase in a competitive market. Yang artinya pelanggan mengevaluasi kualitas dengan membandingkan harapan mereka dengan persepsi mereka tentang kinerja produk. Jika kualitas produk memenuhi harapan pelanggan, pelanggan dikatakan puas ketika kualitas produk melebihi harapan pelanggan, pelanggan dikatakan senang.

P.ISSN: 1410-7988 E.ISSN: 2614-123X 
Selain itu, jika produk gagal memenuhi harapan pelanggan, pelanggan tidak puas dan mungkin tidak ada pembelian berulang di pasar yang kompetitif.

Dalam hal ini, alat ukur kepuasan konsumen yang digunakan dalam penelitian ini adalah menggunakan teori yang dikemukakan oleh Fornell, et al (1996) yaitu teori ACSI (American Customer Satisfaction Index) yang terdiri dari tiga alat ukur yaitu overall quality di mana indikator ini untuk mengetahui peringkat kepuasan konsumen secara keseluruhan, selanjutnya yaitu indikator customization yaitu untuk mengukur sejauh mana kinerja perusahaan dalam menghasilkan suatu produk atau jasa dikatakan gagal atau justru melebihi ekspektasi (harapan) konsumen. Dan indikator terakhir yaitu reliability di mana indikator tersebut digunakan untuk mengukur peringkat kinerja relatif terhadap ideal pelanggan terhadap barang atau jasa tersebut [13].

\section{METODE}

Metode penelitian yang digunakan adalah kuantitatif yang karena data penelitian berupa angka-angka dan analisis menggunakan statistik. metode ini juga bertujuan untuk memperoleh gambaran dari suatu konsep yang berlakku universal pada situasi dan kondisi tertentu.

Dimensi dari variabel kualitas dan inovasi produk dalam penelitian ini diadaptasi dari dimensi penelitian yang digunakan oleh [14] [15] [16] Sedangkan dimensi variabel kepuasan konsumen diadaptasi dari dimensi yang digunakan dalam penelitian yang dilakukan oleh [17] [18] [19]

Populasi penelitian ini adalah konsumen Rabbani di Kota Bandung yang telah melakukan pembelian kerudung minimal satu kali dalam waktu dekat, kemudian ditarik sampel dengan metode purposive sampling hingga diperoleh responden sebesar 150 responden.

Analisis data dalam penelitian ini dimulai dengan analisis deskriptif untuk melihat gambaran data mengenai

Eko dan Bisnis (Riau Economics and Business Reviewe) Volume 10, Nomor 4, 27 Desember 2019 karakteristik responden dan deskripsi variabel penelitian. Kemudian teknik analisis yang digunakan dalam penelitian ini adalah analisis structural equation model (SEM) berbasis Partial Least Square.

Dalam menguji hipotesis digunakan koefiesien parameter dan t-statistik dan masuk dalam inner model. Berikut ini hipotesis yang akan diuji dalam penelitian ini.

H1 : Kualitas produk berpengaruh signifikan dan positif terhadap kepuasan konsumen

$\mathrm{H} 2$ : Inovasi produk berpengaruh signifikan dan positif terhadap kepuasan konsumen.

\section{HASIL}

Pada penelitian ini, jumlah kuesioner yang disebarkan kepada konsumen kerudung Rabbani yang berdomisili di Kota Bandung adalah sebanyak 150 responden.

Tabel 2. Profil Responden

\begin{tabular}{|c|c|}
\hline & Persentase \\
\hline \multicolumn{2}{|l|}{ Lama Usaha } \\
\hline 1.Laki-laki & $6 \%$ \\
\hline 2.Perempuan & $94 \%$ \\
\hline \multicolumn{2}{|l|}{ Usia } \\
\hline $1 . \leq 20$ Tahun & $32.7 \%$ \\
\hline $2 . \overline{2} 1-25$ Tahun & $62.7 \%$ \\
\hline $3.26-30$ Tahun & $3.3 \%$ \\
\hline 4. $\geq 30$ Tahun & $1.3 \%$ \\
\hline \multicolumn{2}{|l|}{ Pekerjaan } \\
\hline 1.Desainer Grafis & $0.7 \%$ \\
\hline 2.Guru & $3.3 \%$ \\
\hline 3. Karyawan & $17.3 \%$ \\
\hline 4. Wiraswasta & $5.4 \%$ \\
\hline 5.Mahasiswa & $64 \%$ \\
\hline 6.Pelajar & $6.7 \%$ \\
\hline 7.PNS & $2 \%$ \\
\hline 8.Santri & $0.7 \%$ \\
\hline \multicolumn{2}{|l|}{ Pendapatan } \\
\hline 1. < Rp. 1.000 .000 & $56 \%$ \\
\hline $\begin{array}{l}\text { 2. Rp. } 1.000 .000-\mathrm{Rp} \text {. } \\
2.000 .000\end{array}$ & $20 \%$ \\
\hline $\begin{array}{l}\text { 3. Rp. } 2.000 .000-\text { Rp. } \\
3.000 .000\end{array}$ & $10 \%$ \\
\hline 4. > Rp. 3.000 .000 & $14 \%$ \\
\hline
\end{tabular}


a. Outer model

\section{1). Uji Validitas Konvergen}

Berikut hasil perhitungan menggunakan program komputer smart PLS 3.0:

Tabel 4.2. Output Result for Outer

\begin{tabular}{l|lll}
\multicolumn{5}{c}{ Loading } \\
\hline & $\begin{array}{l}\text { Kualitas } \\
\text { Produk } \\
\text { (PQ) }\end{array}$ & $\begin{array}{l}\text { Inovasi } \\
\text { Produk } \\
\text { (PIN) }\end{array}$ & $\begin{array}{l}\text { Kepuasan } \\
\text { Pelanggan } \\
\text { (KP) }\end{array}$ \\
\hline PQ1 & 0,810 & & \\
PQ2 & 0,770 & & \\
PQ3 & 0,827 & & \\
PQ4 & 0,759 & & \\
PQ5 & 0,773 & & \\
PQ6 & 0,754 & & \\
PIN1 & & 0,720 & \\
PIN2 & & 0,787 & \\
PIN3 & & 0,760 & \\
PIN4 & & 0,795 & \\
PIN5 & & 0,771 & \\
PIN6 & & 0,805 & \\
KP1 & & & 0,896 \\
KP2 & & & 0,845 \\
KP3 & & & 0,917 \\
\hline \multicolumn{4}{|l}{ Uji Validitas menggunakan validitas }
\end{tabular}

Uji Validitas menggunakan validitas konvergen faktor dengan mengacu pada nilai loading faktor (LF) dan average Variance Extracted (AVE). Dikatakan valid jika nilai LF dan AVE masing-masing item memiliki nilai di atas 0,5 (Latan, 2002).

\section{Uji Validitas Diskriminan}

Pengujian validitas diskriminan (discriminant validity) bertujuan untuk menguji validitas dengan membandingkan nilai pada tabel cross loading. dinyatakan valid jika nilai loading factor lebih tinggi konstruk yang dituju dibandingkan nilai loading factor kepada konstruk lain.

Tabel 4.3. Output Cross Loading

\begin{tabular}{lccc}
\hline & $\begin{array}{c}\text { Kualitas } \\
\text { Produk }\end{array}$ & $\begin{array}{c}\text { Inovasi } \\
\text { Produk }\end{array}$ & $\begin{array}{c}\text { Kepuasan } \\
\text { Pelanggan }\end{array}$ \\
PQ1 & $\mathbf{0 , 8 1 0}$ & 0,502 & 0,499 \\
PQ2 & $\mathbf{0 , 7 7 0}$ & 0,445 & 0,564 \\
PQ3 & $\mathbf{0 , 8 2 7}$ & 0,550 & 0,649 \\
PQ4 & $\mathbf{0 , 7 5 9}$ & 0,552 & 0,494 \\
PQ5 & $\mathbf{0 , 7 7 3}$ & 0,553 & 0,535 \\
PQ6 & $\mathbf{0 , 7 5 4}$ & 0,499 & 0,565
\end{tabular}

Eko dan Bisnis (Riau Economics and Business Reviewe) Volume 10, Nomor 4, 27 Desember 2019

\begin{tabular}{llll} 
PIN1 & 0,613 & $\mathbf{0 , 7 2 0}$ & 0,659 \\
PIN2 & 0,379 & $\mathbf{0 , 7 8 7}$ & 0,356 \\
PIN3 & 0,340 & $\mathbf{0 , 7 6 0}$ & 0,278 \\
PIN4 & 0,349 & $\mathbf{0 , 7 9 5}$ & 0,356 \\
PIN5 & 0,418 & $\mathbf{0 , 7 7 1}$ & 0,389 \\
PIN6 & 0,440 & $\mathbf{0 , 8 0 5}$ & 0,329 \\
KP1 & 0,654 & 0,548 & $\mathbf{0 , 8 9 6}$ \\
KP2 & 0,525 & 0,415 & $\mathbf{0 , 8 4 5}$ \\
KP3 & 0,690 & 0,525 & $\mathbf{0 , 9 1 7}$ \\
\hline
\end{tabular}

\section{Uji Realibilitas}

Berikut ini adalah tabel hasil analisis uji validitas dan uji realibilitas dengan menggunakan SmartPLS 3.0

Table 4.4 Construct Validity and Reliability

\begin{tabular}{llll}
\hline Item & $\begin{array}{l}\text { Cronbac } \\
\text { h Alpha }\end{array}$ & CR & AVE \\
\hline Product Quality & 0,873 & 0,90 & 0,61 \\
Product Innovation & 0,872 & 0,89 & 0,59 \\
Customer & 0,864 & 0,91 & 0,78 \\
\hline
\end{tabular}

Tabel 4.4 menunjukan bahwa seluruh variabel-variabel laten yang diukur dalam penelitian ini memiliki nilai Cronbach's Alpha dan Composite Reliability yang lebih besar dibandingkan dengan 0,7 sehingga dapat dikatakan bahwa semua variabel laten reliabel.

\section{Evaluasi model struktural (Inner Model)}

Evaluasi model struktural pada SEM dengan PLS dilakukan dengan melakukan uji R-squared $\left(\mathrm{R}^{2}\right)$ dan uji signifikansi melalui estimasi koefisien jalur. Pengujian $\mathbf{R}^{2}$

Nilai R-squared $\left(\mathrm{R}^{2}\right)$ dipergunakan untuk megukur seberapa besar pengaruh variabel laten independen tertentu terhadap variabel laten dependen. Hasil menunjukan nilai $\mathrm{R}^{2}$ penelitian ini sebesar 0.52 dapat dikatakan pemodelan yang dibentuk dikategorikan sebagai model yang baik.

\section{Uji Signifikansi}

Uji signifikansi pada model SEM dengan PLS bertujuan untuk mengetahui pengaruh variabel eksogen terhadap variabel endogen. Pengujian hipotesis dengan metode SEM PLS dilakukan dengan 
cara melakukan proses bootstrapping dengan bantuan program komputer smartPLS 3.0 sehingga diperoleh hubungan pengaruh variabel eksogen terhadap variabel endogen sebagai berikut:

Tabel 4.5. Hasil Perhitungan

Bootstrapping Data Penelitian

\begin{tabular}{|c|c|c|c|c|}
\hline & $\begin{array}{l}\text { Original } \\
\text { Sample } \\
\text { (O) }\end{array}$ & $\begin{array}{l}\text { Sample } \\
\text { Mean } \\
\text { (M) }\end{array}$ & $\begin{array}{l}\text { Standard } \\
\text { Deviation } \\
\text { (STDEV) }\end{array}$ & $\begin{array}{l}\mathrm{T} \\
\text { Statistics }\end{array}$ \\
\hline $\begin{array}{l}\text { Inovasi } \\
\text { Produk -> } \\
\text { Kepuasan } \\
\text { Pelanggan }\end{array}$ & 0,171 & 0,179 & 0,080 & 2,128 \\
\hline $\begin{array}{l}\text { Kualitas } \\
\text { Produk -> } \\
\text { Kepuasan } \\
\text { Pelanggan }\end{array}$ & 0,597 & 0,594 & 0,083 & 7,182 \\
\hline
\end{tabular}

hipotesis, diketahui bahwa nilai nilai T-tabel untuk tingkat kepercayaan sebesar 95\% ( $\alpha$ sebesar 5\%) dan derajat kebebasan (df) $=\mathrm{n}-2$ $=150-2=148$ adalah sebesar 1,976.

Berdasarkan hasil output $\mathrm{T}$ statistik untuk variabel Kualitas produk (PQ) terhadap variabel Kepuasan Pelanggan (KP)sebesar 7,182 > T-tabel (1,976). Nilai original sample estimate menunjukan nilai positif sebesar 0,597 yang menunjukan bahwa arah hubungan variabel Kualitas produk (PQ) terhadap variabel Variabel Kepuasan Pelanggan (KP) adalah positif. Dengan demikian $\mathrm{H} 1$ pada penelitian diterima. Artinya, dalam penelitian ini variabel laten Kualitas produk (PQ) dengan indikatorindikatornya berpengaruh terhadap variabel laten Kepuasan Pelanggan (KP) dengan indikator-indikatornya secara signifikan.

Berdasarkan hasil output $\mathrm{T}$ statistik untuk variabel Inovasi produk (PIN) terhadap variabel Kepuasan Pelanggan (KP)sebesar $2,128>$ T-tabel $(1,976)$. Nilai original sample estimate menunjukan nilai positif sebesar 0,171 yang menunjukan bahwa arah hubungan variabel Inovasi produk (PIN) terhadap variabel Variabel Kepuasan Pelanggan (KP) adalah positif. Dengan demikian $\mathrm{H} 1$ pada penelitian diterima. Artinya, dalam penelitian ini variabel laten Inovasi produk (PIN) dengan indikatorindikatornya berpengaruh terhadap variabel

Eko dan Bisnis (Riau Economics and Business Reviewe) Volume 10, Nomor 4, 27 Desember 2019 laten Kepuasan Pelanggan (KP) dengan indikator-indikatornya secara signifikan.

Dari kedua variabel bebas, kualitas produk dan inovasi produk, Diperoleh nilai original sample estimate tertinggi yang mempengaruhi kepuasan pelanggan adalah pada variabel kualitas produk yaitu sebesar p 0,597 dibandingkan dengan variabel inovasi aluproduk hanya sebesar 0,171. Hal ini menunjukan bahwa variabel kualitas produk memiliki pengaruh yang lebih besar 0,034 variabel inovasi produk.

Beberapa fakta yang terbukti dalam o,odßenelitian ini mendukung penelitian sebelumnya terkait pengaruh kualitas produk dengan kepuasan pelanggan. Hasil penelitian Ling \& Mansori (2018) menjelaskan durability, serviceability, aesthetic dan perceive quality yang merupakan indikator dari kualitas produk berpenangaruh terhadap Kepuasan, bahkan cenderung mengarah kepada loyalitas. Begitu juga dengan hasil penelitian Amin \& Onyeukwu (2016) dimana ini kinerja produk menunjukkan $77 \%$ berpengaruh terhadap kepuasan pelanggan.

Dalam penelitian ini juga dilakukan pengujian pengaruh inovasi produk terhadap kepausanya pelanggan. Sebagaimana sudah dijelaskan sebelumnya, inovasi produk juga berpengaruh terhadap kepuasan pelanggan walaupun pengaruhnya tidak sebesar kualitas produk. Hasil penelitian ini juga menguatkan fakta dari penelitian terdahulu. Penelitian Hanaysha \& Hilman (2017) menunjukkan secara empirik terdapat pengaruh yang signifikan dari inovasi produk dan kualitas jasa di dalam kualitas kerelasian. Dan perbedaan level ekonomi dan tingkat teknologi penyebab perbedaan level ekspektasi pelanggan.

\section{SIMPULAN}

Hipotesis dalam peneltian terkait pengaruh kualitas dan inovasi produk terhadap kepuasan pelanggan semuanya terpenuhi. Kualitas produk dan inovasi produk berpengaruh secara positif dan 
signifikan terhadap kepuasan pelanggan walopn dengan tingkt signifikansi yang tidak sama. Di antara semua faktor yang mempengaruhi kepuasan pelanggan, variabel kualitas produk memiliki pengaruh terbesar (koefisien jalur $=0,597$ ). Sedangkan inovasi produk memiliki pengaruh tidak sebesar kualitas produk (koefisien jalur $=0,171$ ). Dari hasil penelitian ini menunjukan bahwa pengguna kerudung Rabbani di Kota bandung dalam memutuskan untuk membeli produk rabani lebih besar pertimbangannya terhadap kualitas produk dibandingkan dengan inovasi produk.

\section{DAFTAR RUJUKAN}

[1] Kementerian perencanaan pembangunan nasional (Bappenas). (2019, 4 Januari). Jumlah Penduduk Indonesia 2019 mencapai 267 juta jiwa. https://databoks.katadata.co.id/datapublis h/. Diakses tanggal 31 Maret 2019

[2] Badan Pusat Statistik. (2018, 5 Februari). Ekonomi Indonesia Triwulan IV. https://www.bps.go.id/pressrelease/.

Diakses tanggal 31 Maret 2019

[3] The pew forum on religion \& public life. (2016, 11 November). Indonesia, negara berpenduduk muslim terbesar dunia. https://databoks.katadata.co.id/datapublis h. Diakses tanggal 31 maret 2019

[4] Devi, S., Sugiharto, S., Pengaruh Product Quality Dan Retail Service Quality Terhadap Repurchase Intention Dengan Customer Familiarity Sebagai Variabel Intervening Pada Store Zara Di Surabaya. Surabaya

[5] Irawan. Top Brand Award. https://www.topbrand-award.com/.

Diakses pada 10 mei 2019

[6] Kotler, P dan Keller, K.L. (2009). Manajemen Pemasaran. Diterjemahkan oleh: Bob Sabran. Tahum terjemah: 2008. Jakarta: Penerbit Erlangga

[7] Kotler, Philip dan Kevin Lane Keller. (2012). Marketing Management Fourteenth Edition. New Jersey: Pearson Education.

Eko dan Bisnis (Riau Economics and Business Reviewe) Volume 10, Nomor 4, 27 Desember 2019
[8] Thamrin, Abdullah dan Tantri, Francis. (2015). Manajemen pemasaran. Jakarta: Rajawali pers.

[9] Garvin, D. A. (1987). Competing on The Eight Dimensions of Quality. Harvard business review, Nov-Dec.

[10] Kaihatu, Thomas S., Achmad, Daengs., \& Agoes, Tinus Lis Indrianto. (2015). Manajemen Komplain. Yogyakarta: Penerbit Andi

[11] Darmadi, Bambang. (2010). Instan Marketing Resep Super Jadi Marketer Hebat. Yogyakarta: penerbit Uaniversitas Atma Jaya Yogyakarta

[12] Kotler, P dan Armstrong, Gary. (2008). Prinsip-prinsip pemasaran. Diterjemahkan oleh: Bob Sabran. Tahun terjemah:2006. Jakarta: Erlangga

[13] Fornell, C., Johnson, M.D., Anderson, E.W., Cha, J., Bryant, B.E. (1996). The american customer satisfaction index: nature, purpose, and findings. Journal of marketing. Vol. 60 No. October.

[14] Atiyah, Latif. (2016). Product's quality and its impact on customer satisfaction a field study in diwaniyah dairy factory. Romania: international management conference "challenges of modern management".

[15] Chen, Ling. H., (2018). The effect of product quality on customer satisfactio and loyalty: Evidence from Malaysian Engineering Industry.

[16] Jakpar, Shaharudin., dan Johari, Anita. (2012). Examinning the product quality attributes that influences customer satisfaction most when the price was discounted: a case study in kuching sarawak. Vol.3, No. 23. International journal of business and social science. December 2012

[17] Gagnon, B. G., \& Sock, Yae, Roh. (2014). The impact of customization and reliability on customer satisfaction in the U.S. lodging industry. No. December. Journal of quality assurance in hospitality \& tourism

[18] Suleiman, M. A. (2012). An application of the american customer P.ISSN: 1410-7988 E.ISSN: 2614-123X 
satisfaction index in the jordaniar mobile phone sector. Vol 24 No. 6. The TQM Journal

[19] Deng, W.J., Yeh, M.L., Sung, M.L. (2013). A customer satisfaction index model for international tourist hotels: integrating consumption emotions into the american customer satisfaction index. Vol. 35. International journal of hospitality management 